\title{
31
}

\section{An election retrospective}

\section{Ratu Joni Madraiwiwi}

The 2006 election confirmed the polarization in the country that has been extant for much of our voting history. The process has tended to ebb and flow at critical periods, with little sign of any sustained development towards integration. The inability of political parties promoting multiracialism and multiculturalism to make inroads was unsurprising. Six years after the events of 2000, divisions remain. Our respective communities continue to find security and support among their kind, and their attitudes are, in turn, reinforced by an electoral system that is ethnically based.

The campaign itself was remarkable for its relative lack of invective, insult and ill will. There were certainly some isolated personal attacks on individual politicians that reflected little credit on the critics. However, by and large, it was open and freewheeling and 'negative' incidents were limited. Radio, television and 'the dailies' provided full coverage and were accessible to the people. The barrage of criticisms leveled at the Electoral Commission and the Supervisor of Elections had some substance, but the problem was largely systemic: the consequence of successive governments since independence leaving those offices in hibernation between elections. The lesson learned is not to allow this to happen in future. The authorities need to ensure that the offices are fully resourced and in a constant state of readiness. There was some defensiveness about the election observers. I take the view that the measure of comfort and assurance they provided the electorate was a sufficient riposte to any criticism. Credit is due the Prime Minister for inviting them.

The election outcome was influenced by several significant factors. I have already mentioned the existing ethnic divisions. The fraught relationship 
between the Soqosoqo ni Duavata ni Lewenivanua (SDL) government and the military, further compounded by the military's campaign for truth and justice in the villages, only served to strengthen support for the SDL. This strengthening was significant in the light of Indo-Fijian emigration coupled with higher Fijian birthrates, neither of which have been given sufficient attention. Next year's census should remedy the situation. What it will reveal, I would respectfully suggest, is the increasing difficulty the Fiji Labour Party (FLP) will face in future elections unless it broadens its Fijian base.

The SDL, and the Prime Minister in particular, were impressive in being able to hold the Fijian electorate together. The calls for unity appear to have been largely heeded. However, differences based on provincial, vanua and other rivalries remain, and will need to be dealt with sensitively and expeditiously if they are to be kept in check. The potential for disunity remains because, as the proportion of Fijians in the population increases, real and imagined grievances are fueled and respective groups feel emboldened to assert their claims. Fijian national leaders have to be more direct in telling their own people about restraint and forbearance. The Pandora's box of ever-increasing expectations in the context of unrealistic time frames is a threat to all of us.

Yet, I do not despair: there is a paradox in these election results that fuels my optimism. The ethnic slant of the voting patterns did not preclude a deepseated desire across our communities for more cooperative governance. Having cast their ballots, the electorate wanted the political parties to work together more closely. In over a century of multiculturalism, much of it with little or any engagement, we have learned to live with each other. We are still learning, sometimes painfully. Part of that lesson is working with each other and engaging in a limited fashion. We prefer our own leaders, but we expect them to build the bridges that we are reluctant to construct ourselves.

As for the National Federation Party, it has failed in a second general election to secure any seats. While I do not predict its demise, it will not make any headway as long as Mr Chaudhry remains leader of the FLP. He is the undisputed political leader of the Indo-Fijian community. His standing was reinforced following the events of May 2000. By his courage while being held hostage in Parliament, he upheld the izzat, or honour, of his people. They have not forgotten and they are grateful. Ironically, it is that status as well as his articulation of Indo-Fijian fears and concerns that make him a bogeyman to 
many Fijians. He is, of course, not one, but rather, a relentless and articulate advocate of the causes in which he believes.

The issues in the election included the Promotion of Reconciliation, Tolerance and Unity Bill, resolution of the land tenure issue, economic management, poverty and the plethora of squatter settlements, as well as the relationship between the government and the military. As is the nature of such debates, there was an ethnic hue to the positions people took. For example, if one was Fijian, one tended to favour the expiring leases being brought under the Native Land Trust Act rather than the Agricultural Landlord and Tenant Act. At the same time, since May 2000, Indo-Fijians see the military as a necessary check on the more nationalist inclinations of the government. The Promotion of Reconciliation, Tolerance and Unity Bill created much disquiet in the community because of its implications. Overall, the support that opposition parties might otherwise have gained from Fijian votes was more than offset by support for the SDL government on the basis of continuing stability.

A pleasing aspect of the new House of Representatives is the eight female members. However, these women represent only a little over ten per cent of the House. There is ample scope for more women representatives. While the FLP adopted a quota system (of sorts) for women candidates at its annual conference in Lautoka in 2004, no political party has been bold enough to implement the initiative. Women have generally had to struggle against heavy odds for endorsement. The arguments about a level playing field are spurious because there is none. Having said that, one must acknowledge the relative success of the SDL government in having five women members of parliament.

In the last few days before the general election commenced on 6 May 2006, advertisements appeared that implied support for the SDL government on the basis of its Christian orientation. Such sentiments had also been expressed from the pulpits in many churches across the nation. Those initiatives were unfortunate and have no place in a multicultural, multireligious society like ours. They influence impressionable minds and thereby encourage bigotry and arrogance. It is sufficient that Christians are enjoined to vote to allow God's will be done. He of course moves in His own unfathomable manner and may use anyone to effect His will. As for the response of Indo-Fijian religious organizations, while more subtle than their Christian counterparts, some could not divorce themselves from the demands of politics, while others remained apolitical. 
The electoral system still remains too complicated for people to understand. However, there is little prospect of change. The major parties appear to be comfortable with the status quo, but that should not be an obstacle to continuing debate and discussion. I do not apologize for favouring a form of proportional representation. It is important that the support for political parties in our community be reflected in that proportion in parliament. Otherwise, certain sections of the electorate are not properly represented. The requirement for a partly pre-determined ethnic composition of the House should also be reviewed with a view to its gradual removal over time. I believe this may happen slowly, as the proportion of Fijians in the population increases significantly, and this scenario provides them with a measure of security.

In the context of the minority General Voter population, the realignment of the United General Party with the FLP generated much soul-searching within these communities. While there were those who feared the consequences of alienation from traditional allies, others were convinced it was time to seek an alternative to the 'step-daughterly' treatment received hitherto. The strategy appears to have worked. Whether it will improve the position of minorities, in terms of the equal opportunities to which they are entitled, is an open question. There are those on the Fijian side of politics who take the view that as 'the generals' have cut loose from their usual moorings, they should be held to account. Politics is not a forgiving pastime here or elsewhere.

It would be easy to feel some disquiet about the continuing ethnic division in our community as revealed in recent voting patterns. I accept such division as largely the result of our history. Yet it also camouflages the accommodations we have made with each other in the years we have lived together. It does not fully reflect the extent of our engagement, although this is still too limited for this author's liking. The strength of this engagement lies in the ordinary people of this country. Twice, almost a decade and a half apart, we have had two significant political upheavals. Our resilience is due in large part to the people and to their hope of a better future for their children, whatever their ethnicity. It is this vision that links all of us. We need to expand the vision to narrow the distances between us and draw us more closely together. For all these reasons and more, the general election of May 2006, with all its imperfections, was a cause for celebration. 